\title{
PHYSIOLOGICAL AND YIELD RESPONSES OF SOME SELECTED RAPESEED/MUSTARD GENOTYPES TO SALINITY STRESS
}

\author{
F. Ahmed ${ }^{1}$, I.M. Ahmed ${ }^{1}$, A.F.M. Shamim Ahsan'1, B. Ahmed ${ }^{1}$ and F. Begum ${ }^{2}$ \\ 1Plant Physiology Division, BARI, Gazipur-1701 \\ ${ }^{2}$ Oil Seed Research Center, BARI, Gazipur-1701 \\ Corresponding E-mail: faruquebari@gmail.com
}

(Received: 12 February 2021, Accepted: 19 February 2021)

Keywords: Salnity, rapeseed/mustard, toerant genotypes, physiological parameters, seed yield

\begin{abstract}
An experiment on rapeseed/mustard genotypes was conducted during 2019-2020 rabi season in vinyl house of Plant Physiology Division of Bangladesh Agricultural Research Institute (BARI), Gazipur to find out the salt-tolerant genotypes based on the responses of their physiological parameters and yield. Five selected rapeseed/ mustard genotypes $\left(\mathrm{V}_{1}=\right.$ Jun-536, $\mathrm{V}_{2}=\mathrm{BJDH}-12, \mathrm{~V}_{3}=\mathrm{BD}-10115, \mathrm{~V}_{4}=\mathrm{BARI}$ Sarisha-14, $\left.V_{5}=B D-6950\right)$ were tested at three salinity levels $\left(S_{0}=0, S_{1}=5\right.$ and $\mathrm{S}_{2}=10 \mathrm{dS} \mathrm{m}^{-1}$ ). Irrespective of the genotypes, salinity stress showed a negative effect on the measured physiological parameters as well as seed yield. Leaf chlorophyll contents, leaf area, leaf photosynthetic rate and total dry matter (TDM) were reduced due to salinity stress which ultimately affected seed yield irrespective of the genotypes. However, these parameters were less affected by the salinity in $V_{1}$ and $V_{2}$ genotypes compared to others. Sodium and potassium ion contents and their ratios $\left(\mathrm{K}^{+} / \mathrm{Na}^{+}\right)$in leaf tissues were significantly affected by salinity stress. Among the genotypes, $\mathrm{V}_{1}$ and $\mathrm{V}_{2}$ showed higher $\mathrm{K}^{+} / \mathrm{Na}^{+}$ratios in leaf under both the salinity treatments, and that phenomenon indicated their higher tolerance to salinity than the other genotypes. Catalase (CAT), Peroxidase (POD) activity and Malondialdehyde (MDA) content of the genotypes increased due to salinity stress with variability among the genotypes. The higher CAT and POD activity with lower MDA content was found in $V_{1}$ and $V_{2}$ genotypes which indicated their better salt tolerance ability compared to others. These genotypes also showed higher seed yield under both the salinity levels $\left(5\right.$ and $\left.10 \mathrm{dS} \mathrm{m}^{-1}\right)$ compared to other genotypes. Based on the responses of physiological parameters and seed yield to salinity, the genotypes Jun-536 $\left(\mathrm{V}_{1}\right)$ and BJDH-12( $\left.\mathrm{V}_{2}\right)$ could be considered relatively tolerant to salinity stress.
\end{abstract}

\section{Introduction}

Salinity is an important limiting factor that causes low crop yield with inferior quality. The adverse effects of salinization cause both osmotic stress and ionic toxicity in plants, leading to secondary stresses such as nutritional disorders and oxidative stress. One of the most detrimental effects of salinity stress is the accumulation of $\mathrm{Na}^{+}$and $\mathrm{Cl}$ ions in tissues of plants exposed to soils with high $\mathrm{NaCl}$ concentrations. Entry of both $\mathrm{Na}^{+}$and $\mathrm{Cl}$ into the cells causes' severe ion imbalance and the excess uptake of them might cause significant physiological disorder(s). Generation of reactive oxygen species (ROS) like singlet oxygen, superoxide radical, hydrogen peroxide, and hydroxyl radicals exposed to salinity stress causes injury to plants. The genotypes which produce more ROS scavenging enzymes under stress can be considered as comparatively tolerant genotype. 
Among the oilseed crops grown in Bangladesh, rapeseed/mustard (Brassica spp.) holds the first position acarage and production. It constitutes an important source of edible oil and is grown under diverse agro-ecological situations. This crop can also be grown successfully in the coastal districts of southern Bangladesh where the cropping intensity is lower than in other parts of the country. However, most of the southern districts of the country are under saline zones which cover an area of $25-30 \%$ of the total cultivable land (SRDI, 2012). Though soil salinity is the most dominant factors limiting crop production in the coastal areas of Bangladesh during dry season, salt-tolerant rapeseed/mustard can bring substantial changes in the agricultural practices in those saline soils. Genetic variations in salt tolerance exist in the glycophytes, and the degree of salt tolerance varies with plant species and varieties within a species. There also exist differences in sensitivity to salinity among Brassica cultivars which need to be found out in a systematic study. Therefore, the present study was conducted to find the tolerant mustardrapeseed genotype(s) based ontolerance of physiological and yield parameters.

\section{Materials and Methods}

A pot experiment on mustard-rapeseed was conducted in the vinyl house of Plant Physiology Division, BARI, Gazipur during the rabi season of 2019-2020. Five selected mustard/rapeseed genotypes, namely: $\mathrm{V}_{1}=$ Jun-536, $\mathrm{V}_{2}=\mathrm{BJDH}-12, \mathrm{~V}_{3}=\mathrm{BD}-10115, \mathrm{~V}_{4}=$ BARISarisha- $14, \mathrm{~V}_{5}=$ BD-6950 was grown in three salinity levels $\left(S_{0}=0, S_{1}=5\right.$ and $\left.S_{2}=10 \mathrm{dS} \mathrm{m}^{-1}\right)$ in pots inside a plastichouse of Plant Physiology Division, BARI, Gazipur during rabi season of 2019-2020. Salinity was imposed at 20 days after sowing by adding $\mathrm{NaCl}$ solution. Salt solution was prepared by dissolving calculated amount of $\mathrm{Lab}$ grade $\mathrm{NaCl}$ with pond water. Salt solution was

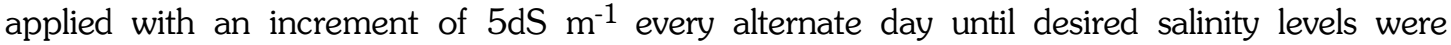
attained. In the control treatment, pond water was used which salinity level was $0.2 \mathrm{dS} \mathrm{m}^{-1}$. Salinity levels were maintained by monitoring and adding salt solution when required up to maturity. The experiment was laid out in a Factorial Randomized Complete Block design with 5 replications. Plastic pots (top dia: $25 \mathrm{~cm}$, bottom dia: $18 \mathrm{~cm}$ and height $25 \mathrm{~cm} ; 12 \mathrm{~kg}$ soil) were filled up with soil and cowdung (4:1). Seeds were sown in each pot on 12 November 2019. Fertilizers were applied @ 100-30-80-20-3-1 kgha-1 NPKSZnB. Half of N and all other fertilizers were applied as basal and the remaining $N$ was applied at 20 days after sowing (DAS). Irrigation was done as and when required for maintaining adequate soil moisture. After emergence plants were thinned to three plants in each pot. Plants from three pots were sampled for leaf area and dry matter measurement at different growth stages. Sampled plants were separated into leaf, stem, and siliqua depending on growth stages. Leaf area was measured by an automatic area meter (LI-3100 C; LI-Cor, USA). Plant parts were dried in an oven for 72 hours at $70^{\circ} \mathrm{C}$ and dry weight was recorded. At harvest yield and yield components data were collected from three pots and analyzed statistically and mean separation was done by LSD test at $5 \%$ level of significance using data processing software.

\section{Chlorophyll estimation}

Leaves of each genotype were properly cut into small pieces and weighed $0.5 \mathrm{~g}$ and were taken for chlorophyll estimation at 55 DAS. Chlorophyll a, chlorophyll $b$ and total chlorophyll were estimated following Arnon's method (Arnon, 1949). The absorbance of the solution was read at 645 and $663 \mathrm{~nm}$ for Chlorophyll a, Chlorophyll b and total chlorophyll.

Calculation:

Chlorophyll a $\left(\mathrm{mg} \mathrm{g}^{-1}\right)=\{12.7(\mathrm{D} 663)-2.69(\mathrm{D} 645)\} \times \mathrm{V} /(1000 \times \mathrm{w})$

Chlorophyll b $\left(\mathrm{mg} \mathrm{g}^{-1}\right)=\{22.9(\mathrm{D} 645)-4.68(\mathrm{D} 663)\} \times \mathrm{V} /(1000 \times \mathrm{w})$ 
Total chlorophyll $\left(\mathrm{mg} \mathrm{g}^{-1}\right)=20.2(\mathrm{D} 645)+8.02(\mathrm{D} 663) \times \mathrm{V} /(1000 \times \mathrm{w})$

Where, $\mathrm{D}=$ optical density; $\mathrm{V}=$ final volume of $80 \%$ acetone $(\mathrm{ml}) ; \mathrm{w}=$ fresh weight of sample taken $(\mathrm{g})$

Leaf photosynthesis measurement: Leaf photosynthetic rate was measured on 50 DAS by a portable photosynthesis system (Li-6800, USA). Fully expanded third leaf from the top was used for this purpose and the measurement was carried out from 10 am to $11.30 \mathrm{pm}$.

Sodium and potassium ion uptake measurement: At 55 DAS, fully expanded third leaf from the top was collected from each treatment for determining of sodium and potassium ion content in leaf tissue. Cell sap of leaf was extracted from the leaf using mortar and pistil. LAQUAtwin Sodium Ion Meter (Na-11, Horiba, Japan) and LAQUAtwin Potassium Ion Meter (K-11, Horiba, Japan) were used for $\mathrm{Na}^{+}$and $\mathrm{K}^{+}$determination, respectively.

\section{Enzyme Extraction and Assays}

Using a pre-cooled mortar and pestle, $0.5 \mathrm{~g}$ of leaf tissue was homogenized in $1 \mathrm{ml}$ of 50 mMice-cold K-phosphate buffer ( $\mathrm{pH} 7.0)$ containing $100 \mathrm{mMKCl}, 1$ mMascorbate, $5 \mathrm{mM} \beta$ mercaptoethanol, and $10 \%(\mathrm{w} / \mathrm{v})$ glycerol. The homogenates were centrifuged at $11,500 \mathrm{~g}$ for $10 \mathrm{~min}$, and the supernatants were used for determining of enzyme activity. All procedures were performed at $0^{\circ} \mathrm{C}$ to $4 \mathrm{C}$.

\section{Determination of Protein}

The protein concentration of each sample was determined following the method of Bradford (1976) using BSA as a protein standard where 5, 10, 15, 20, $25 \mu \mathrm{g} \mu \mathrm{l}^{-1}$ protein concentrations were used to prepare the standard curve.

Peroxidase (POD, EC 1.11.1.7): POD activity was estimated according to Hemeda and Klein (1990). The reaction mixture contained $25 \mathrm{mM} \mathrm{K-P}$ buffer ( $\mathrm{pH} 7.0$ ), 0.05\% guaiacol, $10 \mathrm{mM}$ $\mathrm{H}_{2} \mathrm{O}_{2}$ and enzyme. The activity was determined by the increase in absorbance at $470 \mathrm{~nm}$ due to guaiacol oxidation for 1 min using extinction coefficient of $26.6 \mathrm{mM}^{-1} \mathrm{~cm}^{-1}$.

Catalase (CAT, EC: 1.11.1.6): CAT activity was measured according to the method of Hossain et al. (2010) by monitoring the decrease of absorbance at $240 \mathrm{~nm}$ for $1 \mathrm{~min}$ caused by the decomposition of $\mathrm{H}_{2} \mathrm{O}_{2}$. The reaction mixture contained $50 \mathrm{mM}$ K-phosphate buffer ( $\mathrm{pH}$ 7.0), $15 \mathrm{mM} \mathrm{H}_{2} \mathrm{O}_{2}$, and enzyme solution in a final volume of $0.7 \mathrm{ml}$. The reaction was initiated with enzyme extract, and the activity was calculated using the extinction coefficient of $39.4 \mathrm{M}^{1}$ $\mathrm{cm}^{1}$.

\section{Lipid peroxidation}

The level of lipid peroxidation in plant tissues was expressed as 2-thiobarbituric acid (TBA) reactive metabolites, mainly malondialdehyde (MDA), and was determined according to Hodges et al. (1999). Fresh samples (leaves) of around $0.5 \mathrm{~g}$ were homogenized in $4.0 \mathrm{ml}$ of $1 \%$ trichloroacetic acid (TCA) solution and centrifuged at $10,000 \times \mathrm{g}$ for $10 \mathrm{~min}$. The supernatant was added to $1 \mathrm{ml} 0.5 \%(\mathrm{w} / \mathrm{v})$ TBA made in $20 \%$ TCA. The mixture was heated in boiling water for $30 \mathrm{~min}$, and the reaction was stopped by placing the tubes in an ice bath. The samples were centrifuged at $10,000 \mathrm{~g}$ for $10 \mathrm{~min}$, and the absorbance of the supernatant was recorded at 532 $\mathrm{nm}$. Correction of non-specific turbidity was made by subtracting the absorbance value read at $600 \mathrm{~nm}$. The level of lipid peroxidation was expressed as $\mathrm{nmol} \mathrm{g}^{1}$ fresh weight, with a molar extinction coefficient of $0.155 \mathrm{mMcm}^{1}$. 


\section{Results and Discussion}

\section{Leaf chlorophyll content}

Interaction effect of genotypes and salinity showed significant influence on chlorophyll a content (Fig. 1). Under control conditions (non saline) chlorophyll-a content of the genotypes were identical while chlorophyll-b differed significantly.

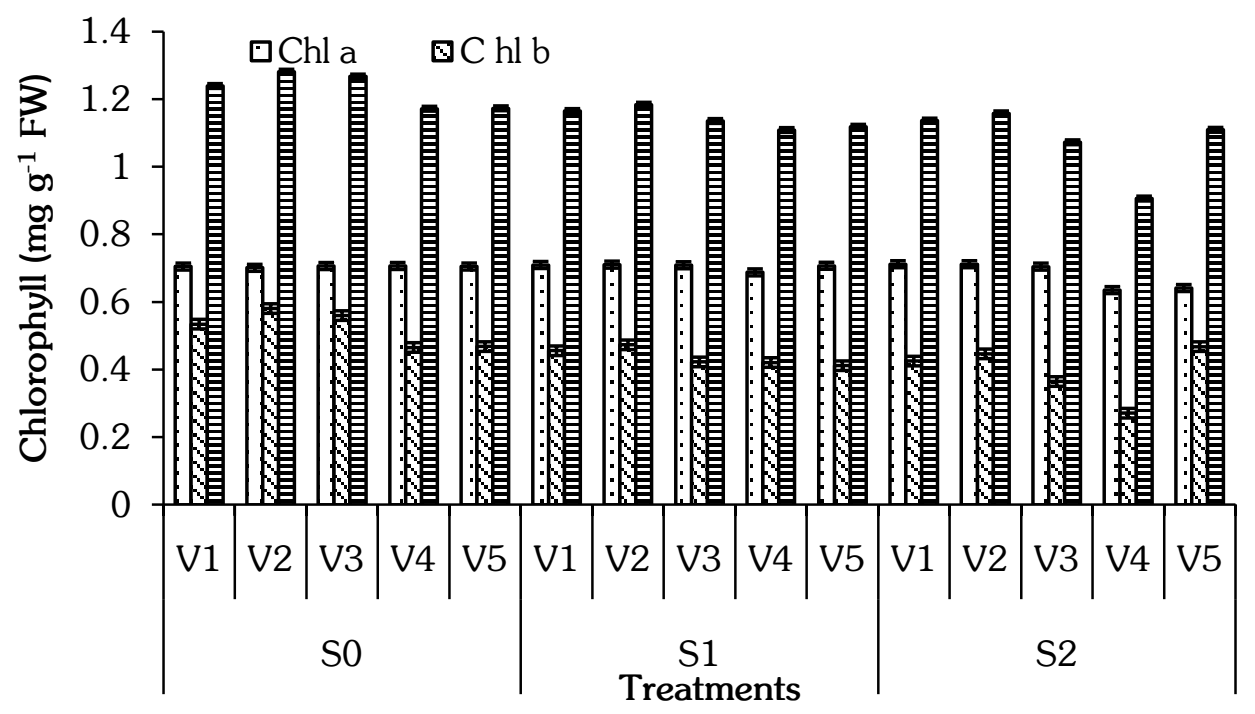

Fig.1. Interaction effect of genotype and salinity on leaf chlorophyll content of mustard/rapeseed at 55 DAS (Vertical bars indicate SE). $V_{1}=$ Jun-536, $V_{2}=$ BJDH-12, V $3=$ BD-10115, V 4 $=$ BARISarisha-14, $\mathrm{V}_{5}=\mathrm{BD}-6950\left(\mathrm{~S}_{0}=0, \mathrm{~S}_{1}=5\right.$ and $\mathrm{S}_{2}=10 \mathrm{dS} \mathrm{m}^{-1}$ salinity $)$.

The maximum chlorophyll-b content was found in $V_{2}$ which was identical with $V_{3}$ but significantly higher than others. The lowest chl $b$ was detected in $V_{4}$ which was identical to that of $V_{5}$. Total chlorophyll content was the highest in $V_{2}$ which was identical with $V_{3}$ but significantly higher than others and the lowest value was found in $V_{4}$. At $5 \mathrm{dS} \mathrm{m}^{-1}$ salinity, all the genotypes showed statistically similar chlorophyll-content except $V_{4}$ which showed the lowest value. Chlorophyll-b content of $V_{1}$ and $V_{2}$ were identical and these values were significantly higher than $V_{3}, V_{4}$ and $V_{5}$ genotypes which showed statistically similar values. The total chlorophyll content of $V_{1}$ and $V_{2}$ were identical but significantly higher than others. At $10 \mathrm{dS} \mathrm{m}{ }^{-1}$ salinity, chlorophyll-a content of $V_{1}, V_{2}$ and $V_{3}$ was identical which were significantly higher than the other two genotypes. Again chlorophyll-a content of $V_{4}$ and $V_{5}$ were statistically similar. The lowest value was found in $V_{4}$. Chlorophyll-b content was the highest in $V_{2}$ which was identical with $V_{1}$ and $V_{5}$ but significantly higher than others. The lowest value was found in $V_{4}$. The total chlorophyll content was the highest in $V_{2}$ which was identical with $V_{1}$ but significantly higher than others. Total chlorophyll content of $V_{3}$ and $V_{5}$ genotypes were identical and the lowest value was found in $\mathrm{V}_{4}$. In general, the photosynthetic pigments i.e. chlorophyll content decreased with the increase of salinity. Shah (2007) also reported reduced chlorophyll content in mustard under salinity stress.

\section{Photosynthesis}

Interaction effect of genotype and salinity showed significant influence on leaf photosynthetic rate (Fig. 2). Under control conditions, the highest photosynthetic rate was found in $V_{5}(23.55$ 
$\mu \mathrm{mol} \mathrm{m} \mathrm{m}^{-2} \mathrm{~s}^{-1}$ ) which were identical with all other genotypes except $V_{4}$ which showed the lowest value. At $5 \mathrm{dS} \mathrm{m}^{-1}$ salinity, the highest photosynthetic rate was observed in $V_{5}$ which was identical with $V_{3}$ and $V_{2}$. Again, $V_{2}$ and $V_{1}$ were identical and the lowest value was found in $V_{4}$ genotype. At $10 \mathrm{dS} \mathrm{m}{ }^{-1}$ salinity, the highest rate was recorded in $V_{2}\left(15.05 \mu \mathrm{molm}^{-2} \mathrm{~s}^{-1}\right)$ which were identical with other genotypes, except $V_{4}$, which showed the lowest value $\left(12.67 \mu \mathrm{mol} \mathrm{m}^{-2}\right.$ $\mathrm{s}^{-1}$ ). In general, with the increase of salinity levels photosynthetic rate was reduced irrespective of the genotypes. Salt-induced reduction in photosynthesis is associated with the partial stomatal closure and/or the non-stomatal limitation which is involved in the dark enzymatic processes of $\mathrm{CO}_{2}$ assimilation e.g. the decrease in Rubisco activity and content, or Pi-regeneration capacity (Ashraf and Harris, 2013).

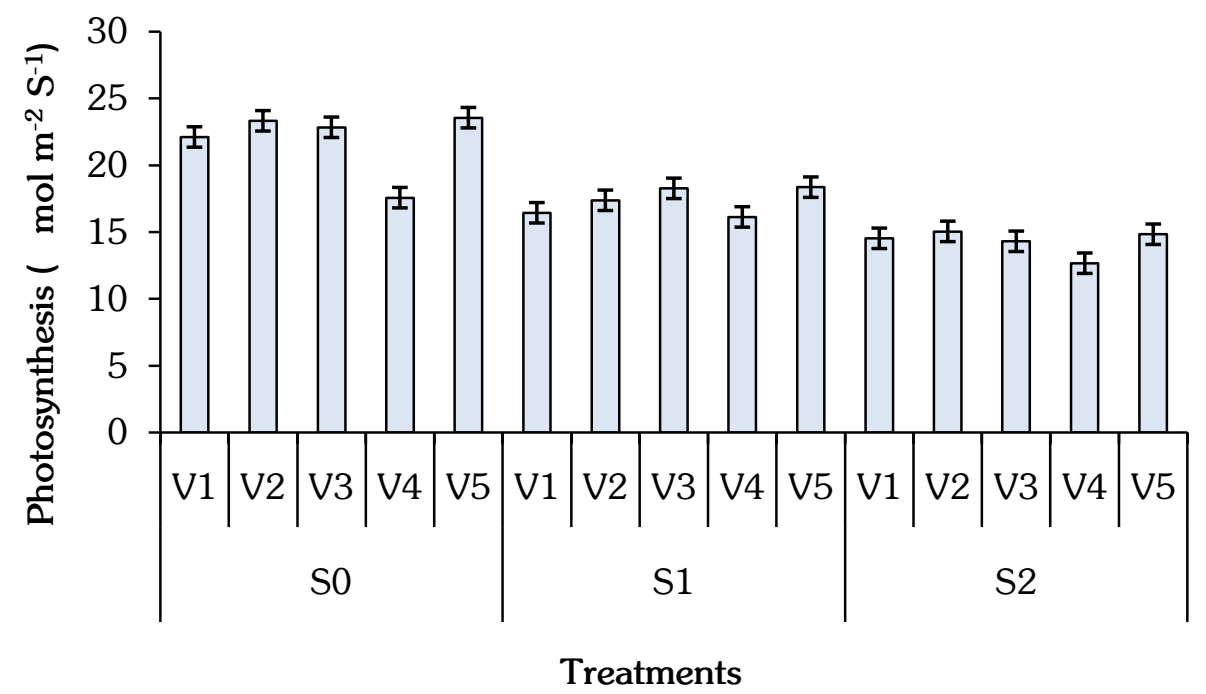

Fig. 2. Interaction effect of genotype and salinity on leaf photosynthesis of mustard/ rapeseed at 55 DAS (Vertical bars indicate SE) $V_{1}=$ Jun-536, $V_{2}=$ BJDH-12, $V_{3}=$ BD-10115, $V_{4}=$ BARI-14, $\mathrm{V}_{5}=$ BD-6950S $\mathrm{S}_{0}=0, \mathrm{~S}_{1}=5$ and $\mathrm{S}_{2}=10 \mathrm{dSm}^{-1}$ salinity.

\section{Leaf area and dry matter production}

Leaf areaplant ${ }^{-1}$ of the mustard-rapessdgenotypes differed significantly under different levels of salinity stress (Table 1). Under control conditions at 45 DAS, the maximum leaf area was observed in $V_{2}\left(410 \mathrm{~cm}^{2}\right)$, which was identical with $V_{1}$ and $V_{3}$. At $5 \mathrm{dS} \mathrm{m}^{-1}$ salinity, the highest leaf area was found in $V_{2}\left(396.67 \mathrm{~cm}^{2}\right)$, which was identical with $V_{1}, V_{3}$ and $V_{5}$ genotypes. The lowest value was found in $V_{4}\left(217.67 \mathrm{~cm}^{2}\right)$ genotype. Under $10 \mathrm{dS} \mathrm{m}^{-1}, \mathrm{~V}_{2}$ produced the highest leaf area $\left(248.33 \mathrm{~cm}^{2}\right)$, which was identical with all other genotypes and the lowest value was observed in $\mathrm{V}_{4}\left(167.67 \mathrm{~cm}^{2}\right)$. In general leaf area was reduced with increased salinity levels irrespective of the genotypes. Salinity-induced osmotic stress is considered responsible for the reduced leaf area in Canola and wild mustard (Huang and Redmann, 1995). Furthermore, high salinity is known to induce ionic stress, which causes premature abscission and senescence of adult leaves, thus reducing the available photosynthetic area (Munns, 2002).

At 55 DAS, under control condition (no salinity), the maximum leaf area was found in $V_{2}$ $\left(438.33 \mathrm{~cm}^{2}\right)$, which was identical with all other genotypes, except $V_{4}$ which produced the lowest leaf area. At $5 \mathrm{dS} \mathrm{m}^{-1}$ salinity, $\mathrm{V}_{2}\left(401.67 \mathrm{~cm}^{2}\right)$ produced the highest leaf area which was identical with all other genotypes except $V_{4}$ which produced the lowest leaf area $\left(246.67 \mathrm{~cm}^{2}\right)$. 
At $10 \mathrm{dS} \mathrm{m}^{-1}$ salinity, the highest leaf area was found in $\mathrm{V}_{2}$ and was identical with all other genotypes except V4 which produced the lowest leaf area $\left(197 \mathrm{~cm}^{2}\right)$. Total dry matter production of the genotypes was identical at 45 DAS under control conditions, although comparatively higher values were observed in $V_{2}\left(8.0 \mathrm{~g} \mathrm{plant}^{-1}\right)$ and $V_{1}\left(7.83\right.$ gplant $\left.^{-1}\right)$ and the lowest $\left(6.93 \mathrm{~g} \mathrm{plant}^{-1}\right)$ in $\mathrm{V}_{4}$. At $5 \mathrm{dSm}^{-1}$ salinity, the highest TDM was found in $\mathrm{V}_{2}(6.98$ gplant $^{-1}$ ) which were identical with all other genotypes except $V_{4}$ which produced the lowest dry matter.

At $10 \mathrm{dSm}^{-1}$ salinity, all the genotypes showed identical values except $V_{4}$ which showed the lowest TDM (4.07 $\mathrm{g}_{\text {plant }}{ }^{-1}$ ). At 55 DAS under control condition, TDM production of $\mathrm{V}_{1}, \mathrm{~V}_{2}$, $V_{3}$ and $V 5$ was identical and the lowest value was found in $V_{4}$. At $5 \mathrm{dS} \mathrm{m} \mathrm{m}^{-1}$ salinity, statistically similar TDM was observed in all the genotypes except $V_{4}$ which was lowest among the genotypes. At $10 \mathrm{dS} \mathrm{m} \mathrm{m}^{-1}$ salinity, the maximum TDM was observed in $V_{1}$ which was identical with $V_{2}$, similarly $V_{2}$ and $V_{3}$ were identical and the lowest value was found in $V_{4}$. At harvest under control condition, TDM production of the genotypes was identical except $V_{4}$ which produced the lowest. At $5 \mathrm{dS} \mathrm{m}^{-1}$ salinity TDM of the genotypes were statistically identical. Under $10 \mathrm{dS} \mathrm{m} \mathrm{m}^{-1}$ salinity, the maximum TDM was found in $V_{1}$ which was identical with $V_{2}, V_{3}$ and $V_{5}$ but lowest in $\mathrm{V}_{4}$. Dry matter production which is considered as an index of photosynthetic activity (Essa and Al-Ani, 2001) was reduced under saline conditions. Reduction in total dry matter accumulation under saline conditions was also reported by Shamsul et al. (2011) in Indian mustard (Brassica juncea).

Table 1. Interaction effect of genotype and salinity on leaf area and TDM of mustard/ rapeseedgenotypes

\begin{tabular}{lcccccc}
\hline Salinity & Genotype & \multicolumn{2}{c}{$\begin{array}{c}\text { Leaf area } \\
\left(\mathbf{c m}^{2}\right)\end{array}$} & \multicolumn{3}{c}{$\begin{array}{c}\text { Total dry matter } \\
\text { (g plant }\end{array}$} \\
& & 1) & \\
\hline & & 45 DAS & 55 DAS & 45 DAS & 55 DAS & Harvest \\
\hline $\mathrm{S}_{0}$ & $\mathrm{~V}_{1}$ & 396.67 & 437.33 & 7.83 & 9.24 & 10.80 \\
& $\mathrm{~V}_{2}$ & 410.00 & 438.33 & 8.00 & 9.17 & 10.20 \\
& $\mathrm{~V}_{3}$ & 389.67 & 401.77 & 7.50 & 9.00 & 10.47 \\
& $\mathrm{~V}_{4}$ & 326.00 & 342.67 & 6.93 & 7.27 & 9.90 \\
& $\mathrm{~V}_{5}$ & 380.33 & 410.67 & 7.10 & 9.00 & 10.20 \\
$\mathrm{~S}_{1}$ & $\mathrm{~V}_{1}$ & 380.00 & 398.67 & 6.83 & 8.88 & 9.33 \\
& $\mathrm{~V}_{2}$ & 396.77 & 401.67 & 6.98 & 8.98 & 9.53 \\
& $\mathrm{~V}_{3}$ & 378.33 & 388.33 & 6.22 & 8.10 & 9.10 \\
& $\mathrm{~V}_{4}$ & 217.67 & 246.67 & 5.49 & 6.83 & 8.20 \\
& $\mathrm{~V}_{5}$ & 365.00 & 391.67 & 6.20 & 8.77 & 9.17 \\
$\mathrm{~S}_{2}$ & $\mathrm{~V}_{1}$ & 244.33 & 303.67 & 5.85 & 7.80 & 8.87 \\
& $\mathrm{~V}_{2}$ & 248.33 & 310.00 & 5.98 & 7.65 & 8.63 \\
& $\mathrm{~V}_{3}$ & 240.00 & 302.00 & 5.63 & 7.67 & 8.25 \\
& $\mathrm{~V}_{4}$ & 167.67 & 197.00 & 4.07 & 5.99 & 7.98 \\
& $\mathrm{~V}_{5}$ & 243.33 & 298.67 & 5.87 & 7.77 & 8.60 \\
\hline LSD (0.05) & & 27.68 & 38.51 & 1.42 & 1.27 & 1.50 \\
CV (\%) & & 5.2 & 6.6 & 11.2 & 9.4 & 9.6 \\
\hline
\end{tabular}

$\mathrm{S}_{0}=0, \mathrm{~S}_{1}=5$ and $\mathrm{S}_{2}=10 \mathrm{dS} \mathrm{m}^{-1}$ salinity. $\mathrm{V}_{1}=\mathrm{Jun} 536, \mathrm{~V}_{2}=\mathrm{BJDH}-12, \mathrm{~V}_{3}=\mathrm{BD}-10115, \mathrm{~V}_{4}=$ BARI-14, $\mathrm{V}_{5}=$ BD-6950.

\section{Potassium and Sodium ion in leaf tissue}

The interaction effect of genotype and salinity on potassium content in leaf tissue was significant (Table 2). Under control conditions, the maximum $\mathrm{K}^{+}$was observed in $\mathrm{V}_{3}(2700 \mathrm{ppm})$ which 
was identical with $V_{1}$ and $V_{2}$ but significantly higher than others. At $5 \mathrm{dS} \mathrm{m} \mathrm{m}^{-1}$, the highest $\mathrm{K}^{+}$was recorded in $V_{4}(2900 \mathrm{ppm})$ and the lowest value was found in the $V_{5}(2300 \mathrm{ppm})$ genotype. At $10 \mathrm{dS} \mathrm{m} \mathrm{m}^{-1}$ salinity, the highest $\mathrm{K}^{+}$was recorded in $\mathrm{V}_{1}(4800 \mathrm{ppm})$ genotype and the lowest value was found in $\mathrm{V}_{4}$ which was identical with $\mathrm{V}_{2}$. The adverse effect of salinity on plant growth may be due to ion cytotoxicity and osmotic stress. High levels of $\mathrm{K}^{+}$in young expanding tissue are associated with salt tolerance in many plant species (Bandeh-Hagh et al., 2008; Shabala, 2009). Sodium content in leaf tissue was significantly lower in the control treatment than other salinity levels irrespective of the genotypes, and the maximum $\mathrm{Na}^{+}$content under no salinity condition was found in $V_{4}$ which was identical with $V_{5}$ but significantly higher than others. Sodium content in leaf tissues increased significantly due to salinity stress irrespective of the genotypes. At $5 \mathrm{dS}$ $\mathrm{m}^{-1}$ salinity, the highest $\mathrm{Na}^{+}$content was found in $\mathrm{V}_{4}(650 \mathrm{ppm})$ and the lowest value was observed in $V_{3}(170 \mathrm{ppm})$ which was identical with $\mathrm{V}_{2}$. At $10 \mathrm{dS} \mathrm{m} \mathrm{m}^{-1}$ salinity, the highest $\mathrm{Na}^{+}$ content was found in $\mathrm{V}_{4}(1400 \mathrm{ppm})$ which was significantly higher than all other genotypes. The lowest $\mathrm{Na}^{+}$content was found in $\mathrm{V}_{2}(260 \mathrm{ppm})$.

The potassium and sodium ion ratio in leaf tissue was drastically reduced due to salinity stress. Genotypes showed significant variability in $\mathrm{K}^{+} / \mathrm{Na}^{+}$ratios in leaf tissue under control conditions. The highest value was found in $V_{2}$ (44.14) which was significantly higher than others. Genotypes $V_{2}$ and $V_{5}$ showed moderate ratios of $\mathrm{K}^{+} / \mathrm{Na}^{+}$content in leaf tissue and the lowest in $\mathrm{V}_{4}$ (14.34). At $5 \mathrm{dS} \mathrm{m} \mathrm{m}^{-1}$ salinity, the maximum value was observed in $\mathrm{V}_{2}$ (13.73) which was identical with all other genotypes and the lowest value was found in $V_{4}$ (4.50). At $10 \mathrm{dS}$ $\mathrm{m}^{-1}$ salinity, the maximum value was observed in $V_{2}(12.70)$ which was identical with $V_{1}(10.97)$ and $\mathrm{V}_{3}(10.92)$ but significantly higher than other genotypes. The lowest value of $\mathrm{K}^{+} / \mathrm{Na}^{+}$ratio was found in $V_{4}(2.23 \mathrm{ppm})$ and $\mathrm{V}_{5}$ showed the moderate value. A decrease in uptake of potassium $(\mathrm{K})$ and consequent decrease in growth at higher sodium $(\mathrm{Na})$ concentration has been reported earlier by Ashraf and McNeilly (2004).

Table 2. Interaction effect of genotype and salinity on potassium and sodium ion uptake and their ratios in mustard/rapeseed genotypes at 55 DAS

\begin{tabular}{lcccc}
\hline Salinity & Genotype & $\mathrm{K}^{+}(\mathrm{ppm})$ & $\mathrm{Na}^{+}(\mathrm{ppm})$ & $\mathrm{K}^{+} / \mathrm{Na}^{+}$ \\
\hline $\mathrm{S}_{0}$ & $\mathrm{~V}_{1}$ & 2500 & 68 & 36.87 \\
& $\mathrm{~V}_{2}$ & 2600 & 59 & 44.14 \\
& $\mathrm{~V}_{3}$ & 2700 & 120 & 22.78 \\
& $\mathrm{~V}_{4}$ & 2400 & 170 & 14.34 \\
$\mathrm{~S}_{1}$ & $\mathrm{~V}_{5}$ & 2200 & 110 & 20.03 \\
& $\mathrm{~V}_{1}$ & 2500 & 210 & 11.91 \\
& $\mathrm{~V}_{2}$ & 2600 & 190 & 13.73 \\
& $\mathrm{~V}_{3}$ & 2300 & 170 & 13.55 \\
$\mathrm{~S}_{2}$ & $\mathrm{~V}_{4}$ & 2900 & 650 & 4.50 \\
& $\mathrm{~V}_{5}$ & 2500 & 220 & 11.52 \\
& $\mathrm{~V}_{1}$ & 4800 & 440 & 10.97 \\
& $\mathrm{~V}_{2}$ & 3300 & 260 & 12.70 \\
& $\mathrm{~V}_{3}$ & 4000 & 370 & 10.92 \\
$\mathrm{LSD}(0.05)$ & $\mathrm{V}_{4}$ & 3100 & 1400 & 2.23 \\
$\mathrm{CV}(\%)$ & $\mathrm{V}_{5}$ & 4400 & 580 & 7.61 \\
\hline
\end{tabular}

$\mathrm{S}_{0}=0, \mathrm{~S}_{1}=5$ and $\mathrm{S}_{2}=10 \mathrm{dS} \mathrm{m}^{-1}$ salinity. $\mathrm{V}_{1}=\mathrm{Jun} 536, \mathrm{~V}_{2}=\mathrm{BJDH}-12, \mathrm{~V}_{3}=\mathrm{BD}-10115, \mathrm{~V}_{4}=$ BARI-14, $\mathrm{V}_{5}=$ BD-6950. 


\section{Antioxidant activity}

Antioxidant activity was significantly affected due to salinity stress (Fig. 3). Under control treatment, higher catalaze (CAT) activities were found in $V_{5}$ and lower in $V_{2}$. At $5 \mathrm{dS} \mathrm{m}^{-1}$ salinity, the highest CAT activity was observed in $V_{2}$ which was significantly higher than others.

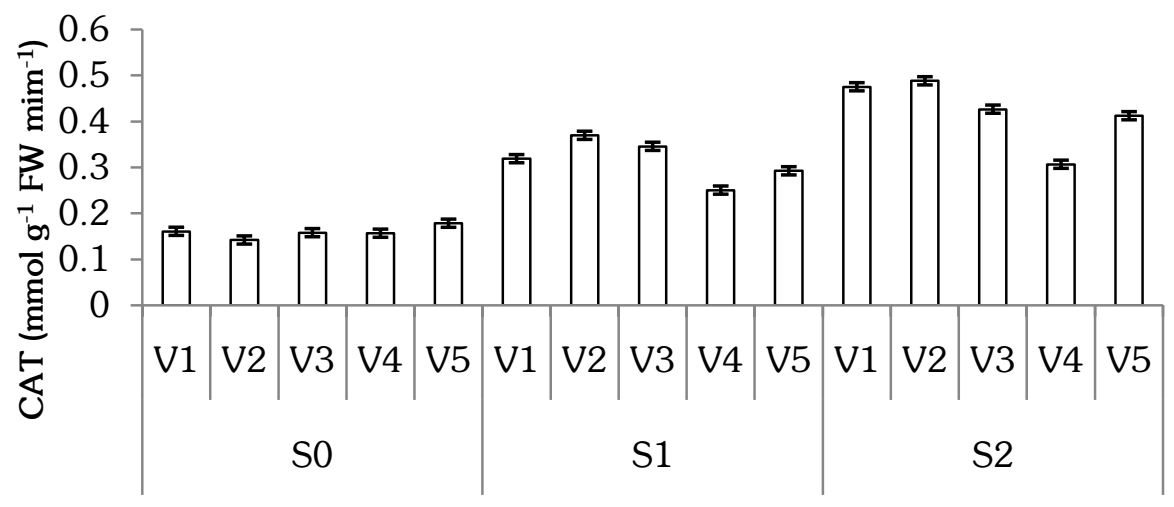

Treatments

Fig. 3. Effect of salinity stress on the catalyze activity in rapeseed/mustard genotypes at 55DAS. (Vartical bar indicate SE). $\mathrm{V}_{1}=$ Jun-536, $\mathrm{V}_{2}=\mathrm{BJDH}-12, \mathrm{~V}_{3}=\mathrm{BD}-10115, \mathrm{~V}_{4}=\mathrm{BARI}$ $14, \mathrm{~V}_{5}=\mathrm{BD}-6950 . \mathrm{S}_{0}=0, \mathrm{~S}_{1}=5$ and $\mathrm{S}_{2}=10 \mathrm{dS} \mathrm{m} \mathrm{m}^{-1}$ salinity.

At $10 \mathrm{dS} \mathrm{m}^{-1}$ salinity CAT activity was higher than control and $5 \mathrm{dS} \mathrm{m}^{-1}$ salinity and the maximum activity was observed in $V_{2}$ which was identical with $V_{1}$ but significantly higher than others. CAT activity of $V_{3}$ and $V_{5}$ were identical and the lowest was found in $V_{4}$. Peroxidase (POD) activity also increased due to temperature stress compared to control (Fig.4). Under control conditions, comparatively higher POD activity was found in $V_{5}$ followed by $V_{2}$ and $V_{1}$ and the lower in $V_{4}$ and $V_{3}$. At $5 \mathrm{dS} \mathrm{m} \mathrm{m}^{-1}$ salinity the highest POD activity was observed in $V_{2}$ which was significantly higher than other. At $10 \mathrm{dS} \mathrm{m}{ }^{-1}$ salinity POD activity of $V_{1}, V_{2}$ and $V_{5}$ were satirically identical, $\mathrm{V}_{3}$ showed moderate activity while the lowest was found in $\mathrm{V}_{4}$. The reduced rate of photosynthesis increases the formation of reactive oxygen species (ROS) and increases the activity of enzymes (CAT and POD) that detoxify the ROS (Foyer and Noctor, 2005).

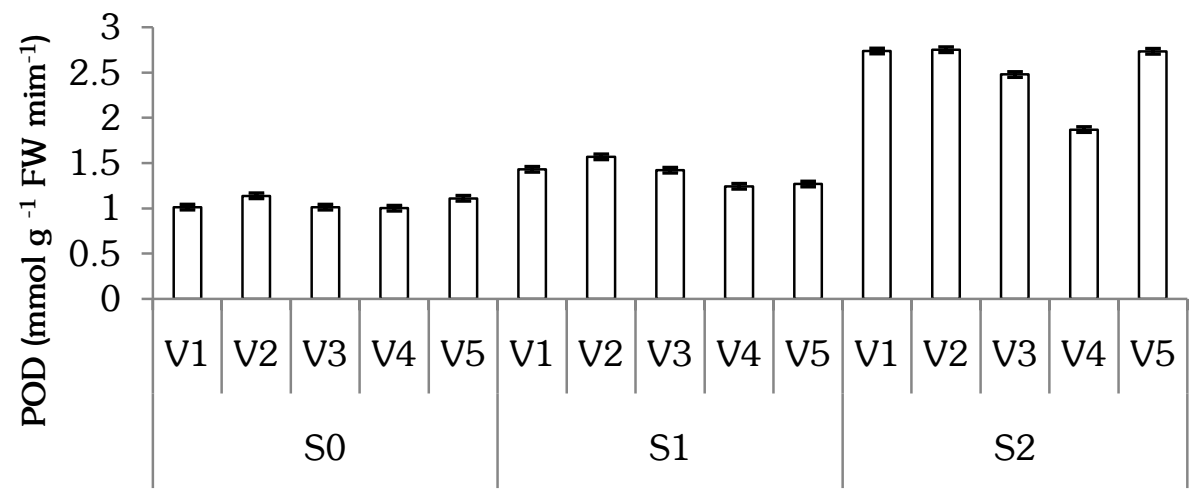

Treatments

Fig. 4. Effect of salinity stress on the POD activity in rapeseed/mustard genotypes at 55 DAS (Varticalbars indicateSE). $\mathrm{V}_{1}=$ Jun-536, $\mathrm{V}_{2}=\mathrm{BJDH}-12, \mathrm{~V}_{3}=\mathrm{BD}-10115, \mathrm{~V}_{4}=$ BARI-14, $\mathrm{V}_{5}=\mathrm{BD} 6950 \mathrm{~S}_{0}=0, \mathrm{~S}_{1}=5$ and $\mathrm{S}_{2}=10 \mathrm{dS} \mathrm{m}^{-1}$ salinity. 
Malondialdehyde (MDA) content also increased due to salinity stress compared to control (Fig. 5). Under control conditions, the genotypes showed variability in MDA activity which increased with the increase in salinity levels. At $5 \mathrm{dS} \mathrm{m} \mathrm{m}^{-1}$ salinity, the maximum MDA activity was foun in $\mathrm{V}_{4}$ followed by $V_{5}$ and $V_{3}$, and the lowest was found in $V_{2}$. At $10 \mathrm{dS} \mathrm{m} \mathrm{m}^{-1}$ salinity, almost a similar trend was observed where the highest MDA was found in $V_{4}$ and the lowest in $V_{2}$. Higher MDA content in the cell is correlated with salt stress sensitivity while lower MDA content displays higher antioxidative ability, reflecting higher tolerance to stress (Noreen and Ashraf, 2009).

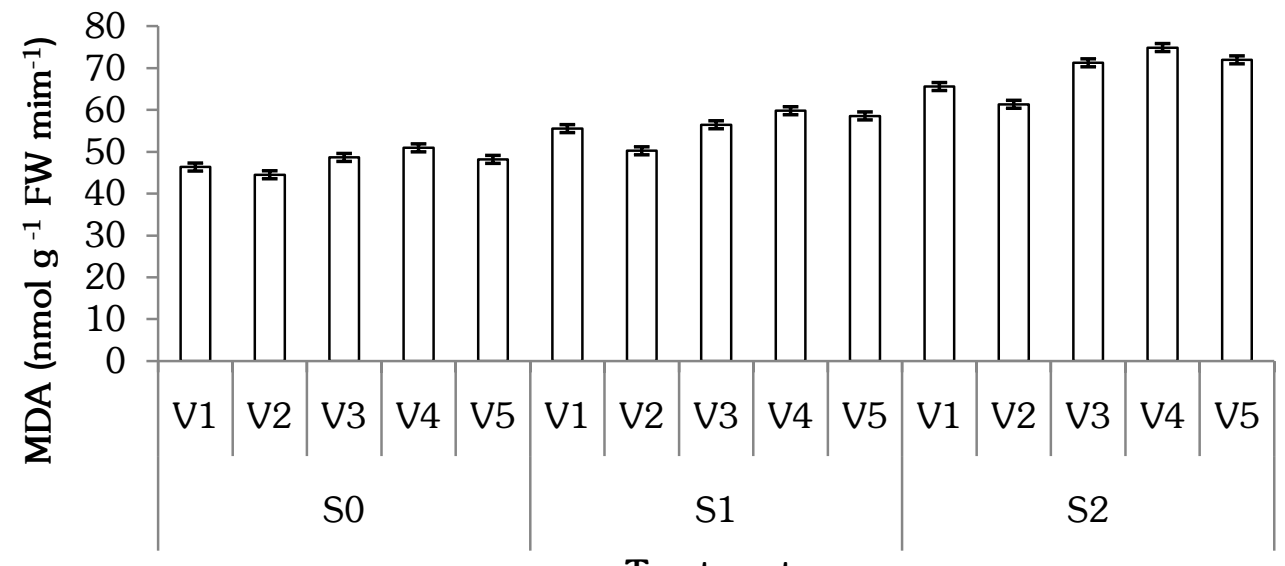

Treatments

Fig. 5. Effect of salinity stress on the MDA activity in rapeseed-mustard genotypes at 55 DAS (Vertical bars indicate $\pm S E$ ). $V_{1}=$ Jun-536, $V_{2}=B J D H-12, V_{3}=B D-10115, V_{4}=$ BARI14, $\mathrm{V}_{5}=$ BD-6950. $\mathrm{S}_{0}=0, \mathrm{~S}_{1}=5$ and $\mathrm{S}_{2}=10 \mathrm{dS} \mathrm{m}^{-1}$ salinity.

\section{Yield and yield contributing characters}

\section{Effect of genotypes}

Genotypes showed significant difference in plant height (Table 3). The tallest plant was found in $V_{3}(127.33 \mathrm{~cm})$ which was significantly higher than all other genotypes. Siliquaplant ${ }^{-1}$ of the genotypes also varied significantly. The highest number of siliquaplant ${ }^{-1}$ was recorded in $V_{5}$ (115.82) and the lowest siliquaplant ${ }^{-1}$ was recorded in $V_{4}$ (57.37) genotype. The number of seedssiliqua $^{-1}$ of the genotypes differed significantly.

Table 3. Effect of genotype on yield and yield component of mustard/rapeseed

\begin{tabular}{lccccc}
\hline Genotype & $\begin{array}{c}\text { Plant } \\
\text { height }(\mathbf{c m})\end{array}$ & $\begin{array}{c}\text { No. of siliqua } \\
\text { plant }^{-1}\end{array}$ & $\begin{array}{c}\text { No. of seeds } \\
\text { siliqua }^{-1}\end{array}$ & $\begin{array}{c}\text { 1000-seed } \\
\text { weight (g) }\end{array}$ & $\begin{array}{c}\text { Seed yield } \\
\text { plant }^{\mathbf{1}}(\mathbf{g})\end{array}$ \\
\hline $\mathrm{V}_{1}$ & 117.96 & 94.56 & 13.44 & 2.97 & 3.55 \\
$\mathrm{~V}_{2}$ & 100.59 & 95.26 & 13.99 & 3.19 & 3.91 \\
$\mathrm{~V}_{3}$ & 127.33 & 79.74 & 15.69 & 3.10 & 3.59 \\
$\mathrm{~V}_{4}$ & 73.56 & 57.37 & 25.84 & 3.27 & 2.91 \\
$\mathrm{~V}_{5}$ & 110.37 & 115.82 & 13.24 & 2.80 & 3.26 \\
\hline $\mathrm{LSD}(0.05)$ & 7.56 & 13.45 & 2.22 & 0.27 & 0.31 \\
$\mathrm{CV}(\%)$ & 7.50 & 10.50 & 11.40 & 9.30 & 9.60 \\
\hline
\end{tabular}

$\mathrm{V}_{1}=$ Jun536, $\mathrm{V}_{2}=$ BJDH-12, $\mathrm{V}_{3}=\mathrm{BD}-10115, \mathrm{~V}_{4}=$ BARI-14, $\mathrm{V}_{5}=$ BD-6950. 
The highest number of seedssiliqua ${ }^{-1}$ was observed in $V_{4}$ (25.84) which were significantly higher than other genotypes and the lowest value was observed in $V_{5}$ (13.24). The seed size of the genotypes varied significantly. The highest 1000 -seed weight was recorded in $V_{4}(3.27 \mathrm{~g})$ which was significantly higher than others and the lowest was recorded in $V_{5}(2.80 \mathrm{~g})$. Seed yieldplant ${ }^{-1}$ of the genotypes varied significantly. The highest seed yield was found in $V_{2}$ which significantly higher than others. But the lowest yield was observed in $V_{4}$.

\section{Effect of salinity}

Salinity stress significantly affected yield and yield contributing characters of rapeseed/mustard genotypes (Table 4). Plant height was significantly reduced due to salinity stress. The tallest plant was recorded in control $(125.44 \mathrm{~cm})$ condition while the shortest in $10 \mathrm{dS} \mathrm{m}^{-1}$ salinity treatment $(86.29 \mathrm{~cm})$.

Table 4. Effect of salinity on yield and yield components of rapeseed/mustard

\begin{tabular}{lccccc}
\hline Salinity & $\begin{array}{c}\text { Plant } \\
\text { height } \\
\text { (cm) }\end{array}$ & $\begin{array}{c}\text { No. of siliqua } \\
\text { plant }^{-1}\end{array}$ & $\begin{array}{c}\text { No. of seeds } \\
\text { siliqua }^{-1}\end{array}$ & $\begin{array}{c}\text { 1000-seed } \\
\text { weight } \\
\text { (g) }\end{array}$ & $\begin{array}{c}\text { Seed } \\
\text { yieldplant }\end{array}$ \\
\hline $\mathrm{S}_{0}$ & 125.44 & 91.64 & 17.39 & 3.29 & 4.16 \\
$\mathrm{~S}_{1}$ & 100.16 & 85.18 & 16.50 & 3.09 & 3.38 \\
$\mathrm{~S}_{2}$ & 86.29 & 76.82 & 15.42 & 2.82 & 2.79 \\
\hline $\mathrm{LSD}_{(0.05)}$ & 5.85 & 10.42 & 1.72 & 0.21 & 0.24 \\
$\mathrm{CV}(\%)$ & 7.50 & 10.50 & 11.40 & 9.30 & 9.60 \\
\hline
\end{tabular}

$\mathrm{S}_{0}=0, \mathrm{~S}_{1}=5$ and $\mathrm{S}_{2}=10 \mathrm{dS} \mathrm{m}^{-1}$

The most common undesirable effect of salinity on the crop of Brassica is the reduction in plant height, component characters of yield as well as deterioration of the product quality (Zamani et al., 2010). Siliquaplant ${ }^{-1}$ was significantly reduced due to salinity stress, the highest number was observed in the control (91.64) condition which was identical with $5 \mathrm{dS} \mathrm{m} \mathrm{m}^{-1}$ salinity level and the lowest (76.82) in $10 \mathrm{dSm}^{-1}$. A negative effect of salinity on the number of siliqua plant ${ }^{-1}$ of $^{-1}$ Indian mustard was also observed by Kripa et al. (2011). The highest number of seedssiliqua-1 was found in the control conditions (17.39) which was identical with $5 \mathrm{dS} \mathrm{m}^{-1}$ and the lowest (15.42) in $10 \mathrm{dS} \mathrm{m}^{-1}$ salinity. These results corroborate the findings of Ahmad (2010). Reduced seed size was observed due to salinity stress. The highest 1000 -seed weight was found in the control conditions (3.29 g) which was significantly higher than others and the lowest $(2.82 \mathrm{~g})$ in $10 \mathrm{dS} \mathrm{m} \mathrm{m}^{-1}$ salinity. Seed yield was also reduced due to salinity stress and the highest seed yield (4.16gplant ${ }^{-1}$ ) was recorded in the control conditions and the lowest $\left(2.79\right.$ gplant $\left.^{-1}\right)$ in $10 \mathrm{dS} \mathrm{m}^{-1}$ salinity. This finding is supported by Kripa et al. (2011).

\section{Interaction effect of genotype and salinity on seed yield}

Interaction effect of genotype and salinity showed significant influence on seed yieldplant ${ }^{-1}$ (Fig.6). Under control conditions, the seed yield of $V_{1}$ and $V_{2}$ were identical. At $5 \mathrm{dS} \mathrm{m}^{-1}$ salinity the maximum seed yield was found in $V_{2}$ which was identical with $V_{1}, V_{3}$ and $V_{5}$ but significantly higher than $V_{4}$. At $10 \mathrm{dS} \mathrm{m} \mathrm{m}^{-1}$ salinity $\mathrm{V}_{2}$ showed the highest seed yield which was significantly higher than other. The lowest yield was found in $V_{4}$ genotype. Salinity may reduce the crop yield by upsetting the water and nutritional balance of plants (Francois, 1994; Islam et al., 2001). 


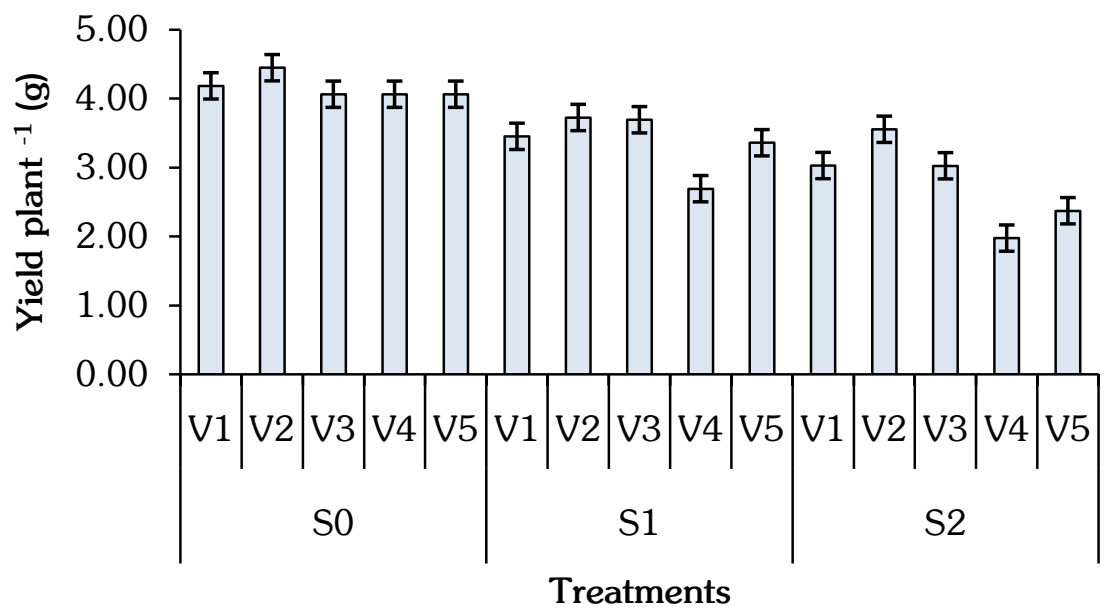

Fig. 6. Interaction effect of genotype and salinity on the seed yield of rapeseed/mustard (Vertical barsindicate SE) $\mathrm{V}_{1}=$ Jun-536, $\mathrm{V}_{2}=\mathrm{BJDH}-12, \mathrm{~V}_{3}=\mathrm{BD}-10115, \mathrm{~V}_{4}=$ BARI Sarisha-14, $\mathrm{V}_{5}=\mathrm{BD}-6950 . \mathrm{S}_{0}=0, \mathrm{~S}_{1}=5$ and $\mathrm{S}_{2}=10 \mathrm{dS} \mathrm{m}^{-1}$ salinity.

\section{Conclusion}

Results revealed that genotypes Jun-536 and BJDH-12 were comparatively salt-tolerant as evaluated based on seed yield and important physiological parameters.

\section{References}

Ahmad, B. 2010. Effects of salinity on yield and component characters in canola (Brassica napus L.) cultivars. Not. Sci. Biol. 2(1): 81-83.

Arnon, D.I. 1949. Copper enzymes in isolated chloroplasts. Polyphenoloxidase in Beta vulgaris. Plant Physiol. 24: 1.

Ashraf, M. and P.J.C. Harris. 2013. Photosynthesis under stressful environments: An overview. Photosynthetica 51: 163-190.

Ashraf, M. and T. Mcneilly. 2004. Salinity tolerance in Brassica oilseeds. Critical Rev. Plant Sci. 23(2): 157-174.

Bandeh-Hagh, A., M. Toorchi, A. Mohammadi, N. Chaparzadeh, G.H. Salekdeh and H.Kazemnia. 2008. Growth and osmotic adjustment of canola genotypes in response to salinity. J. Food Agric. Environ. 6(2):201-208.

Bradford, M.M. 1976. A rapid and sensitive method for the quantitation of microgram quantities of protein utilizing the Principle of Protein-Dye Binding. Anal. Biochem. 72: 248-254.

Chakraborty, K., R.K. Sairam and R.C. Bhattacharya. 2012. Differential expression of salt overly sensitive pathway genes determines salinity stress tolerance in Brassica genotypes. Plant Physiol. Biochem. 51:90-101.

Essa, A.T. and D.H. Al-Ani. 2001. Effect of salt stress on the performance of six soybean genotypes. Pakistan. J. Biol. Sci. 4: 175-177.

Foyer, C.H. and G. Noctor. 2005. Oxidant and antioxidant signalling in plants: a re-evaluationof the concept of oxidative stress in a physiological context. Plant Cell Environ.28:1056-71. 
Francois, L.E. 1994. Growth, seed yield, and oil content of canola grown under saline environments. Agron. J. 86(2):233-237.

Hemeda, H.M. and B.P. Klein. 1990. Effects of naturally occurring antioxidants on peroxidase activity of vegetable extracts. J. Food Sci. 55: 184-185.

Hodge, D.M., J.M. DeLong, C.F. Forney and R.K. Prange. 1999. Improving the thiobarbituric acidreactive-substance assay for estimating lipid peroxidation in plant tissues containing anthocyanin and other interfering compounds. Planta 207(4): 604-611.

Hossain, M.A., M. Hasanuzzaman and M. Fujita. 2010. Up-regulation of antioxidant and glyoxalase systems by exogenous glycinebetaine and proline in mungbean confer tolerance to cadmium stress. Physiol. Mol. Biol. Plants 16: 259-272.

Huang, J. and R.E. Redmann. 1995. Physiological responses of Canola and wild mustard to salinity and contrasting calcium supply. J. Plant Nutr. 18(9): 1931-1949.

Islam, M.R., M.A.R. Bhuiyan, B. Prasad and M.A. Quddus. 2001. Salinity effect on yield andcomponent characters in rapeseed and mustard varieties. J. Biol. Sci. 1(9):840-842.

James, R.A., C. Blake, C.S. Byrt and R. Munns. 2011. Major genes for Na+ exclusion, Nax1 and Nax2 (wheat HKT1; 4 and HKT1; 5), decrease Na+ accumulation in bread wheat leaves under saline and waterlogged conditions. J. Expt. Bot. 62(8): 2939-2947.

Khan, N.A. 2003. NaCl inhibited chlorophyll synthesis and associated changes in ethylene evolution and antioxidative enzyme activities in wheat. Biol. Plant. 47: 437-440.

Khan, N.A., H.R. Ansari, M. Khan and R.M. Samiullah. 2002. Effect of phytohormones on growth and yield of Indian mustard. Indian J. Plant Physiol. 7: 75-78.

Kim, Y., J. Arihara, T. Nakayama, N. Nakayama, S. Shimada and K. Usui. 2004. Antioxidative responses and their relation to salt tolerance in Echinochloa oryzicola vasing and Seteriavirdis (L.) Beauv. Plant Growth Regul. 44: 87-92.

Kripa, S., S.K.S. Parihar, K. Kuldeep, D. Kant and K. Arun. 2011. Relative salt tolerance of Indian mustard (Brassica juncea) genotypes in relation to germination, growth and seed yield. J. Oilseed Brassica. 2(2): 76-82.

Marschner, H. 1986. Mineral nutrition in higher plants. Academic Press, London, pp.477-542.

Mehmood, A., A. Hussain, M. Irshad, M. Hamayun, A. Iqbal and N. Khan. 2019. In vitro production of IAA by endophytic fungus Aspergillusawamori and its growth promoting activities in Zea mays. Symbiosis 77: 225-235.

Munns, R. 2002. Comparative physiology of salt and water stress. Plant Cell Environ. 25: 239-250.

Noreen, Z. and M. Ashraf. 2009. Assessment of variation in antioxidative defense system in salttreated pea (Pisumsativum) cultivars and its putative use as salinity tolerance markers. J. Plant Physiol. 166(16): 1764-1774.

Shabala, S. 2009. Salinity and programmed cell death: unraveling mechanisms for ion specific signaling. J. Expt. Bot. 60:709-712.

Shabala, S. 2013. Learning from halophytes: Physiological basis and strategies to improve abiotic stress tolerance in crops. Ann. Bot. 112: 1209-1221.

Shah, S.H. 2007. Effects of salt stress on mustard as affected by gibberellic acid application. Gen. Appl. Plant Physiol. 33(1-2): 97-10.

Shamsul, H., B.A. Mir, A.S. Wani, S.A. Hasan, I. Mohd and A. Aqil. 2011. Screening of salt-tolerant genotypes of Brassica juncea based on photosynthetic attributes J. Plant Interactions. 6(1): 53-60.

Shrivastava, P. and R. Kumar. 2015. Soil salinity: a serious environmental issue and plant growth promoting bacteria as one of the tools for its alleviation. Saudi J. Biol. Sci. 22:123-131. 
Song, X.S., W.H. Hu, W.H. Mao, J.O. Ogweno, Y.H. Zhou and J.Q. Yu. 2005. Response of ascorbate peroxidase isoenzymes and ascorbate regeneration system to abiotic stresses in Cucumis sativus L. Plant Physiol. Biochem. 43(12): 1082-1088.

SRDI. 2012. Saline soils of Bangladesh. Soil Resources and Development Institute. Ministry of Agriculture, Farmgate, Dhaka-1215.

Sudhir, P. and S.D.S. Murthy. 2004. Effects of salt stress on basic processes of photosynthesis. Photosynthetica, 42:481- 486.

Xia, X.J., C.J. Gao, S.L. Xong, Y.H. Zhou, K.A.I. Shi and J.Q. Yu. 2014. Role of $\mathrm{H}_{2} \mathrm{O}_{2}$ dynamics in brassinosteroid-induced stomatal closure and opening in Solanum lycopersicum. Plant Cell Environ. 37: 2036-2050.

Zamani Z., M.T. Nezami, D. Habibi and M.B. Khorshidi. 2010. Effect of quantitative and qualitative performance of four canola cultivars (Brassica napus L.) to salinity conditions. Adv. Environ. Biol. 4(3): 422-427. 